\title{
Ion Exchange Properties of the Erythrocyte Surface Protein Band 3 and its Role in the Process of Oxygenation during CMV Infection in the Third Trimester of Pregnancy
}

\author{
Michael T. Lucenko, PhD, ScD*; Irina A. Andrievskaya, PhD, ScD; Artem G. Mironenko \\ Far Eastern Scientific Center of Physiology and Pathology of Respiration, \\ Siberian Branch of the Russian Academy of Sciences \\ Blagoveshchensk, the Russian Federation
}

\begin{abstract}
The aim of our study was to determine the nature of the ion exchange properties of EPB3 and its participation in the process of oxygenation with CMV infection (CMVI) in the third trimester of pregnancy.

Material and methods: The study included 105 pregnant women (the third trimester of gestation from 26 to 32 weeks): 35 CMV-seropositive pregnant women (the main group - Group 1) with CMVI exacerbation and anti-CMV IgG antibody titer of 1:1600, $35 \mathrm{CMV}$-seropositive pregnant women (the comparison group - Group 2) with latent CMVI and an anti-CMV IgG antibody titer of 1:800, and $35 \mathrm{CMV}$-seronegative pregnant women (the control group).

The study of the protein spectrum of the erythrocyte membrane was carried out by analytical separation in the presence of $0.1 \%$ SDS on a one-dimensional $7.5 \%-10 \%$ gradient polyacrylamide gel. The oxyhemoglobin content was determined spectrophotometrically by the method of Malloy and Evelyn (1969); the total and bound-to-hemoglobin ATP and the total and inorganic phosphorus were determined by IS Luganov and MN Blinov (1975), the activity of ouabain-sensitive Na+/K+-ATPase by Kazennova's method (1986) and the levels of $\mathrm{Na}+$ and $\mathrm{K}+$ in plasma and RBCs by using "Vital Best" (Russia) sets.

Results: CMVI exacerbation in the third trimester of pregnancy is associated with a decrease in the content of EPB3 in RBC membranes due to increased proteolytic processes, which causes disturbances in its structural and functional properties. Thus, ion transport and association of the cytoplasmic domain of the protein with deoxyhemoglobin are changed and disrupt the processes of oxygenation. (Int J Biomed. 2016; 6(4):271-275.)
\end{abstract}

Key words: cytomegalovirus $(C M V) \bullet$ erythrocyte surface protein band $3(E P B 3) \bullet$ pregnancy $\bullet N a+/ K+$-ATPase $\bullet$ oxyhemoglobin

\section{Introduction}

Erythrocyte, like every cell, has an outer shell, which separates its internal contents from the external environment. The inner layer directly adjacent to the cell cytosol is called the cytoplasmic membrane. The cell membrane provides elasticity, strength, and stability, and it has the ability to deform when red blood cells (RBCs) pass through the narrow holes of capillaries..$^{[1]}$ These properties are supported by the lipid-protein complex of the erythrocyte membranes. ${ }^{[2]}$ Proteins belonging

*Corresponding author: Prof. Michael Lucenko, Academician of the RAS, Head of Far Eastern Scientific Center of Physiology and Pathology of Respiration SB of the RAS, Blagoveshchensk, Russia. E-mail:Lucenkomt@mail.ru to the membrane, depending on their location and functional properties, are divided into peripheral and integral peptides. Of particular importance is the erythrocyte surface protein band 3 (EPB3), which has a wide range of properties. ${ }^{[3]}$ EPB3 binds cytoskeletal proteins (spectrin and ankyrin) to the cytoplasmic membrane, which provides structural integrity and a biconcave shape to erythrocytes. ${ }^{[4]}$ According to other research, terminal NH2-groups of EPB3 are associated with deoxyhemoglobin ${ }^{[5]}$ and enzymes of glycolysis. ${ }^{[6]}$ These data also show that deoxyhemoglobin competes with glycolytic enzymes for the binding site on the EPB3 that leads to the reversible displacement of the glycolytic enzymes from the membrane and changes their catalytic properties in response to changes in $\mathrm{PO}_{2}{ }^{[7]}$ Also, it has been proved the role of the 
EPB3 - deoxyhemoglobin interactions in the regulation of erythrocyte volume modulated by activity of $\mathrm{Na}+/ \mathrm{K}+-$ channels and specific ATPases associated with them. ${ }^{\left[{ }^{8]}\right.}$ However, the stability of the proteinaceous cytoskeleton of RBC membranes can be exposed to toxic effects of various kinds, including the action of viruses. Previously we have shown the impact of the persistent herpesvirus and cytomegalovirus (CMV) infections on structural and functional properties of the peripheral blood erythrocyte, including during pregnanc $\mathrm{c}^{\mathrm{y} \cdot[9]}$

The aim of our study was to determine the nature of the ion exchange properties of EPB3 and its participation in the process of oxygenation with CMV infection (CMVI) in the third trimester of pregnancy.

\section{Material and Methods}

The study was conducted in the laboratory of pathogenesis and regenerative processes of the respiratory system in non-specific lung diseases and the department of pregnancy pathology of the Far Eastern Scientific Center of Physiology and Pathology of Respiration of the RAS (Blagoveshchensk, Russia). The study was approved by the local Ethics Committee. Written informed consent was obtained from all participants.

The study included 105 pregnant women (the third trimester of gestation from 26 to 32 weeks): 35 CMVseropositive pregnant women (the main group - Group 1) with CMVI exacerbation and anti-CMV IgG antibody titer of 1:1600, $35 \mathrm{CMV}$-seropositive pregnant women (the comparison group - Group 2) with latent CMVI and an anti-CMV IgG antibody titer of 1:800, and $35 \mathrm{CMV}$-seronegative pregnant women (the control group).

Inclusion criteria for the main group were a relapse of CMVI identified by molecular biological and serological methods and anti-CMV IgG antibody titer of 1:1600, as well as herpes virus infection (HHV-1,2) remission during the entire gestation period.

Exclusion criteria were primary CMVI, an aggravation of other inflammatory diseases of extragenital localization and sexually transmitted infections.

The relapse of CMVI was diagnosed in a comprehensive study of the peripheral blood to check for the presence of IgM or a fourfold or more increase in anti-CMV IgG antibody titer in paired serum in the dynamics after 10 days, an avidity index $>65 \%$, and the presence of CMV DNA in samples of blood, urine, buccal epithelium, and cervical mucosa.

Blood samples $(5 \mathrm{ml})$ were collected from the ulnar vein in standard vacuum tubes with EDTA to obtain the samples of mononuclear cells. For serological tests, we used blood that does not contain anticoagulants. Mononuclear cell isolation for PCR was carried out with Ficoll-Urografin (d-1,077g/ ml) ("DNA-Technology", Russia). Serological studies were performed in paired serum samples at intervals of 10-14 days. The morning urine specimens for PCR analysis were collected in a sterile container $(60 \mathrm{ml})$. Buccal epithelium and contents of the cervical canal were collected in standard sterile plastic tubes $(0.5 \mathrm{ml})$ with a physiological solution.

For CMV verification, the type-specific antibodies (IgG and $\operatorname{IgM}$ ) and avidity index were determined by ELISA on the microplate reader "StatFax 2100" (USA) using the sets of CC "Vector-Best" (Russia). CMV DNA was detected by PCR on a DT-96 machine using sets of "DNA-Technology" (Russia).

The study of the protein spectrum of the erythrocyte membrane was carried out by analytical separation in the presence of $0.1 \%$ SDS on a one-dimensional $7.5 \%$ $10 \%$ gradient polyacrylamide gel. ${ }^{[10]}$ Polypeptide bands were stained in a $0.1 \%$ solution of Coomassie R-250, a $50 \%$ alcohol solution, and a $7 \%$ acetic acid solution. The electrophoregrams identification was carried out at a wavelength of 590-600 nm using BioDocAnalize machine (Germany). The oxyhemoglobin content was determined spectrophotometrically by the method of Malloy and Evelyn ${ }^{\text {[11] }}$ using StatFax-1900 (US); the total and bound-to-hemoglobin $\mathrm{Hb}$ ) ATP and the total and inorganic phosphorus (Pt and Pi) were determined by IS Luganov and MN Blinov, ${ }^{[12]}$ the activity of ouabain-sensitive $\mathrm{Na}+/ \mathrm{K}+$-ATPase by Kazennova's method, ${ }^{[13]}$ and the levels of $\mathrm{Na}+$ and $\mathrm{K}+$ in plasma and $\mathrm{RBCs}$ by using "Vital Best" (Russia) sets.

Statistical analysis was performed using StatSoft Statistica v6.0. The mean (M) and standard error of the mean (SEM) were calculated. Multiple comparisons were performed with oneway ANOVA and post-hoc Tukey HSD test. A probability value of $P<0.05$ was considered statistically significant.

\section{Results}

The EPB3 level in Group 1 was 1.22 times less than in the control group $(P=0.0000)$ and 1.19 times less than in Group $2(P=0.0000)$ (Table 1$)$, which indicated an increase in the proteolytic degradation of protein components of the erythrocyte membrane and the destabilization of its properties caused by the increased expression of CMV antigens during CMVI exacerbation. In Group 2, we did not find statistically significant differences compared to the control group.

In assessing the state of the energy balance of RBCs of peripheral blood, which reflects the state of the processes of protein phosphorylation, we identified a reduction in the levels of total and bound-to-hemoglobin ATP that causes disorders in the structural and functional properties of the membrane and its components, including EBP3. The total ATP level was 1.4 times less than in the control group $(P=0.0002)$ and 1.2 times less than in Group $2(P=0.0202)$ (Table 1$)$. The level of bound-to-hemoglobin ATP was 1.29 times less than in the control group $(P=0.0000)$ and 1.2 times less than in Group $2(P=0.0000)$ (Table 1). In Group 2, we found statistically significant differences compared to the control group only for the level of bound-to-hemoglobin ATP $(P=0.0004)$.

The obtained results showed an increase in the content of total and inorganic phosphorus in RBCs of peripheral blood in pregnant women of Group 1 compared to the control group, which indicated an increase in ATP hydrolysis, as well as in the catalytic activity of glycolytic enzymes responsible for the synthesis of 2,3-DPG. In Group 2, we found statistically significant differences compared to Group 1 only for the level of total phosphorus. 
Table 1.

EPB3, ATP, the ionic composition of the blood plasma and RBCs, and the $\mathrm{Na}^{+} / \mathrm{K}^{+}-$ATPase activity in pregnant women with $C M V I$ in the third trimester of pregnancy

\begin{tabular}{|c|c|c|c|c|}
\hline Variable & $\begin{array}{c}\text { Group } 1 \\
\text { (1) }\end{array}$ & $\begin{array}{c}\text { Group } 2 \\
\text { (2) }\end{array}$ & $\begin{array}{c}\text { Control group } \\
\text { (3) }\end{array}$ & Statistics \\
\hline EPB3, \% & $15.00 \pm 0.12$ & $17.83 \pm 0.17$ & $18.34 \pm 0.19$ & $\begin{array}{l}\text { ANOVA } P=0.0000 \\
\text { Tukey HSD Post-hoc Test } \\
P_{1-2}=0.0000 P_{1-3}=0.0000 \\
P_{2-3}=0.0731^{\prime}\end{array}$ \\
\hline Total ATP, $\mu \mathrm{mol} / \mathrm{ml}$ & $0.51 \pm 0.03$ & $0.64 \pm 0.03$ & $0.71 \pm 0.04$ & $\begin{array}{l}\text { ANOVA } P=0.0002 \\
\text { Tukey HSD Post-hoc Test } \\
P_{1-2}=0.0202 P_{1-3}=0.0002 \\
P_{2-3}=0.3094^{\prime}\end{array}$ \\
\hline АТФ per $1 \mathrm{~g} \mathrm{Hb} . \mu \mathrm{mol} / \mathrm{ml}$ & $4.4 \pm 0.05$ & $5.3 \pm 0.07$ & $5.7 \pm 0.09$ & $\begin{array}{l}\text { ANOVA } P=0.0000 \\
\text { Tukey HSD Post-hoc Test } \\
P_{1-2}=0.0000 P_{1-3}=0.0000 \\
P_{2-3}=0.0004\end{array}$ \\
\hline $\mathrm{Pt}, \mu \mathrm{mol} / \mathrm{ml}$ & $0.158 \pm 0.005$ & $0.145 \pm 0.003$ & $0.139 \pm 0.003$ & $\begin{array}{l}\text { ANOVA } P=0.0020 \\
\text { Tukey HSD Post-hoc Test } \\
P_{1-2}=0.0443 P_{1-3}=0.0017 \\
P_{2-3}=0.5036\end{array}$ \\
\hline $\mathrm{Pi}, \mu \mathrm{mol} / \mathrm{ml}$ & $0.102 \pm 0.005$ & $0.093 \pm 0.002$ & $0.087 \pm 0.002$ & $\begin{array}{l}\text { ANOVA } P=0.0072 \\
\text { Tukey HSD Post-hoc Test } \\
P_{1-2}=0.1386 P_{1-3}=0.0052 \\
P_{2-3}=0.4101^{\prime}\end{array}$ \\
\hline $\mathrm{Na}^{+} / \mathrm{K}^{+}$-ATPase, $\mu \mathrm{mol} \mathrm{Pi} / \mathrm{mlEr} / \mathrm{hr}$ & $2.02 \pm 0.10$ & $2.85 \pm 0.11$ & $3.15 \pm 0.10$ & $\begin{array}{l}\text { ANOVA } P=0.0000 \\
\text { Tukey HSD Post-hoc Test } \\
P_{1-2}=0.0000 P_{1-3}=0.0000 \\
P_{2-3}=0.1055^{\prime}\end{array}$ \\
\hline plasma $\mathrm{Na}^{+}, \mathrm{mmol} / \mathrm{ml}$ & $145.93 \pm 0.72$ & $144.40 \pm 0.68$ & $143.80 \pm 0.49$ & $\begin{array}{l}\text { ANOVA } P=0.0561 \\
\text { Tukey HSD Post-hoc Test } \\
P_{1-2}=0.2117 P_{1-3}=0.0522 \\
P_{2-3}=0.7842\end{array}$ \\
\hline $\mathrm{Na}^{+}$in $\mathrm{RBC}, \mathrm{mmol} / \mathrm{ml}$ & $125.53 \pm 1.13$ & $122.27 \pm 0.45$ & $121.23 \pm 0.79$ & $\begin{array}{l}\text { ANOVA } P=0.0012 \\
\text { Tukey HSD Post-hoc Test } \\
P_{1-2}=0.0190 P_{1-3}=0.0013 \\
P_{2-3}=0.6552^{\prime}\end{array}$ \\
\hline plasma $\mathrm{K}^{+}, \mathrm{mmol} / \mathrm{ml}$ & $3.89 \pm 0.07$ & $3.71 \pm 0.03$ & $3.35 \pm 0.03$ & $\begin{array}{l}\text { ANOVA } P=0.0000 \\
\text { Tukey HSD Post-hoc Test } \\
P_{1-2}=0.0223 P_{1-3}=0.0000 \\
P_{2-3}=0.0000^{\prime}\end{array}$ \\
\hline $\mathrm{K}^{+}$in $\mathrm{RBC}, \mathrm{mmol} / \mathrm{ml}$ & $2.75 \pm 0.18$ & $3.52 \pm 0.06$ & $4.14 \pm 0.09$ & $\begin{array}{l}\text { ANOVA } P=0.000 \\
\text { Tukey HSD Post-hoc Test } \\
P_{1-2}=0.0001 P_{1-3}=0.0000 \\
P_{2-3}=0.0013\end{array}$ \\
\hline
\end{tabular}

In Group 1, the identified patterns in decreasing levels of total and bound-to-hemoglobin ATP were associated with a decrease in the catalytic activity of ouabain-sensitive $\mathrm{Na}+\mathrm{K}+$ ATPase that, apparently, caused a disorder in phosphorylation of the transmembrane domain of EBP3 in the process of its catalytic cycle, and in the transport and translocalization of ions $\mathrm{Na}+$ and $\mathrm{K}+$ across the plasma membrane. In Group 1, we found significantly decrease in the $\mathrm{Na}+/ \mathrm{K}+$-ATPase activity (in 1.56 times) compared to the control group $(P=0.0000)$ and Group 2 (in 1.4 times) $(P=0.0000)$. In Group 2, the $\mathrm{Na}+/ \mathrm{K}+-$ ATPase activity did not change significantly compared to the control group.

In assessing the ionic composition of the blood plasma and RBCs in pregnant women of Group 1 and Group 2, we revealed the opposite changes in the content of $\mathrm{Na}+$ and $\mathrm{K}+$ (Table 1). Thus, we observed a moderate increase in the concentration of $\mathrm{Na}+$ ions in the plasma and $\mathrm{RBCs}$ in Group 1 compared to the control group $(P=0.0522$ and $P=0.0013)$ and Group $2(P=0.2117$ and $P=0.019)$. In Group 2, we did not find statistically significant differences compared to the control group. When calculating the ratio between the content of $\mathrm{Na}+$ ions in the plasma and erythrocytes, we found a moderate reduction in this parameter only in Group $1(1.16 \pm 0.01$ vs $1.19 \pm 0.01$ in the control group, $P<0.05)$, which indicated an increase in the intracellular $\mathrm{Na}+$ level, resulting in an increase in the dehydration and modulation of $\mathrm{RBC}$ volume.

In analyzing the content of $\mathrm{K}+$ ions in the blood plasma (Table 1), we found a significant increase in this parameter in Groups 1 and 2 compared to the control group $(P=0.0000$ in both cases). In Group 1, this increase was more pronounced. In RBCs, on the contrary, the levels of $\mathrm{K}+$ ions decreased in Groups 1 and 2 compared to the control group $(P=0.0000$ and $P=0.0013)$. In Group 1 , this increase was more pronounced. The ratio between the contents of $\mathrm{K}+$ ions in the plasma and 
erythrocytes was significantly increased in Groups 1 and 2 compared to the control group, indicating a decrease in intracellular ion concentration.

The established changes in the ratio of $\mathrm{Na}^{+}$and $\mathrm{K}+$ ions and their transport through the transmembrane domain of EBP3 will contribute to disrupting the formation of electronegative potential of the erythrocyte membrane, causing a violation of the hemoglobin oxygenation process and the formation of its oxygenated form. This statement is confirmed by our results. Thus, in Group 1, we observed a decrease in the level of oxygenated $\mathrm{Hb}$ on the background of a low total $\mathrm{Hb}$ level compared to Group 2 and the control group (Table 2). Indicators of oxyhemoglobin in Group 1 were significantly decreased compared to Group 2 and the control group. In Group 2, we found statistically significant differences compared to the control group only for the level of total $\mathrm{Hb}$.

\section{Table 2.}

The levels of total Hb and oxyhemoglobin in RBCs of the peripheral blood of pregnant women with CMVI in the third trimester of pregnancy

\begin{tabular}{|l|c|c|c|l|}
\hline Variable & $\begin{array}{c}\text { Group 1 } \\
(1)\end{array}$ & $\begin{array}{c}\text { Group 2 } \\
(2)\end{array}$ & $\begin{array}{c}\text { Control } \\
\text { group (3) }\end{array}$ & \multicolumn{1}{|c|}{ Statistics } \\
\hline $\begin{array}{l}\text { Total Hb, } \\
\text { g/l }\end{array}$ & $\begin{array}{r}11.00 \\
\pm 0.22\end{array}$ & $\begin{array}{r}12.00 \\
\pm 0.15\end{array}$ & $\begin{array}{l}13.00 \\
\pm 0.20\end{array}$ & $\begin{array}{l}\text { ANOVA } P=0.0000 \\
\text { Tukey HSD Post-hoc Test } \\
P_{1-2}=0.0011 P_{1-3}=0.0000 \\
P_{2-3}=0.0011^{\prime}\end{array}$ \\
\hline $\begin{array}{l}\text { Oxy-Hb, } \\
\%\end{array}$ & $\begin{array}{l}89.00 \\
\pm 0.55\end{array}$ & $\begin{array}{l}97.00 \\
\pm 0.23\end{array}$ & $\begin{array}{l}98.00 \\
\pm 0.45\end{array}$ & $\begin{array}{l}\text { ANOVA } P=0.0000 \\
\text { Tukey HSD Post-hoc Test } \\
P_{1-2}=0.0000 P_{1-3}=0.0000 \\
P_{2-3}=0.2338^{\prime}\end{array}$ \\
\hline
\end{tabular}

\section{Discussion}

According to the study, CMVI exacerbation in the third trimester of pregnancy increases the expression of the antigen on the surface of RBCs, which facilitates the penetration of toxic proteins tegument deep into the cells. This is followed by the launch of a cascade of hydrolytic and proteolytic processes, disturbing the protein-protein and lipid-protein interactions and leading to a redistribution in the ratio of proteins. The proof of this fact was the decreasing EBP3 content in RBC membranes of peripheral blood of CMV-seropositive pregnant women with CMVI exacerbation compared with the latent course of CMVI and CMV-seronegative pregnant women. These changes may be the result of possible conformational changes due to oxidative modification, which breaks the association of EBP3 with ankyrin and the plasma membrane as a whole. ${ }^{[4]}$ A disturbance in the structural integrity of EBP3 increases its affinity to deoxyhemoglobin in the cytoplasmic part, inducing thereby conformational and functional changes in the transmembrane domains of the protein. ${ }^{[3,7]}$ These changes lead to a change in electronegativity of the erythrocyte membrane through inactivation of interfacial interactions with the ion transporter $(\mathrm{Na}+/ \mathrm{K}+$-ATPase), weakening phosphorylation of the transmembrane domains of EBP3, resulting in compensatory increases in the catalytic activity of the glycolytic enzymes associated with the cytoplasmic domain of the protein, which regulate the synthesis of 2,3-DPG. ${ }^{[14,15]}$ As a result, the number of bonds between deoxyhemoglobin and 2,3-DPG is increased, which reduces the affinity of hemoglobin for oxygen and the formation of its oxygenated forms. This fact is confirmed by a decrease in the EBP3 level and in the activity of the $\mathrm{Na}+/ \mathrm{K}+$-ATPase in erythrocytes of the peripheral blood in CMV-seropositive pregnant women; we also found an increase in the content of inorganic phosphate and a reduction in the amount of ATP and total and oxygenated $\mathrm{Hb}$ in Group 1 compared with the latent course of CMVI.

\section{Conclusion}

Thus, CMVI exacerbation in the third trimester of pregnancy is associated with a decrease in the content of EPB3 in RBC membranes due to increased proteolytic processes, which causes disturbances in its structural and functional properties. Thus, ion transport and association of the cytoplasmic domain of the protein with deoxyhemoglobin are changed and disrupt the processes of oxygenation. The latter circumstance forms a threat for the development hypoxia-related disorders in CMV-seropositive women in the third trimester of pregnancy.

\section{Competing interests}

The authors declare that they have no conflict of interest.

\section{References}

1. Novitsky VV, Ryazantseva NV, Stepovaya EA. Physiology and pathophysiology of the erythrocytes. Tomsk: Publishing House of Tomsk University Press; 2004, 202 pp. [in Russian]. 2. Storozhok SA, Sannikov AG, Belkin AV. Stability of deformation properties of erythrocyte membranes depending on the molecular interactions of proteins of the cytoskeleton. Scientific Bulletin of Tyumen State University. 2008; 3:123-32. [in Russian].

3. Campanella ME, Markley JL, Low PS. Role of band 3 in regulating metabolic flux of red blood cells. Proc Natl Acad Sci USA. 2009.106(44):18515-20.

4. Chang SH, Low PS. Identification of a critical ankyrinbinding loop on the cytoplasmic domain of erythrocyte membrane band 3 by crystal structure analysis and sitedirected mutagenesis. J Biol Chem. 2003;278(9):6879-84.

5. Chu H, Breite A, Ciraolo P, Franco RS, Low PS. Characterization of the deoxyhemoglobin binding site on human erythrocyte band 3: implications for $\mathrm{O} 2$ regulation of erythrocyte properties. Blood. 2008;111(2):932-8.

6. Chu H, Low PS. Mapping of glycolytic enzymebinding sites on human erythrocyte band 3 . Biochem J. 2006;400(1):143-51.

7. Campanella ME, Chu H, Low PS. Assembly and regulation of a glycolytic enzyme complex on the human erythrocyte membrane. Proc Natl Acad Sci USA. 2005; 102(7):2402-7.

8. Khan AI, Drew C, Ball SE, Ball V, Ellory JC, Gibson JS. Oxygen dependence of $\mathrm{K}(+)-\mathrm{Cl}-$ cotransport in human red cell 
ghosts and sickle cells. Bioelectrochemistry. 2004;62(2):141-6. 9. Lucenko MT, Andrievskaya IA. Morphofunctional changes in erythroid elements in norm and pathology. New York: IMRDC; 2014:125 pp.

10. Maurer G. Disc electrophoresis. M.; Meditsina; 1971, 154 pp. [in Russian].

11. Biochemical methods of investigation: a handbook. Ed. by A.A. Pokrovsky. M.: Meditsina; 1969, 337 pp. [in Russian].

12. Luganova IS, Blinov MN. Determination of 2,3-diphosphoglyceric acid by a nonenzymatic method and levels of 2,3-diphosphoglycerate and ATP in the erythrocytes of patients with chronic lympholeukemia. Lab Delo.
1975;(11):652-4. [in Russian].

13. Kazennov AM, Maslova MN, Shalabodov AD. Na K ATPase activity in mammalian erythrocytes. Biokhimiia. 1984;49(7):1089-95. [in Russian].

14. Richard V, Dodson GG, Mauguen Y. Human deoxyhaemoglobin-2,3-diphosphoglycerate complex low-salt structure at 2.5 A resolution. J Mol Biol. 1993; 233(2):270-4. 15. Weber RE, Voelter W, Fago A, Echner H, Campanella E, Low PS. Modulation of red cell glycolysis: interactions between vertebrate hemoglobins and cytoplasmic domains of band 3 red cell membrane proteins. Am J Physiol Regul Integr Comp Physiol. 2004;287(2):454-64. 